\title{
Response Surface Methodology Optimization of an Acidic Protease Produced by Penicillium bilaiae Isolate TDPEF30, a Newly Recovered Endophytic Fungus from Healthy Roots of Date Palm Trees (Phoenix dactylifera L.)
}

\author{
Fedia Ben Mefteh ${ }^{1,2}$, Fakher Frikha ${ }^{2}$, Amal Daoud ${ }^{2}$, Ali Chenari Bouket ${ }^{1}{ }^{1}$, \\ Lenka Luptakova ${ }^{1,3}$, Faizah N. Alenezi ${ }^{1}$, Bader S. Al-Anzi ${ }^{4}$, Tomasz Oszako 5 (i), \\ Neji Gharsallah ${ }^{2}$ and Lassaad Belbahri ${ }^{1,6, *(D)}$ \\ 1 NextBiotech, 98 Rue Ali Belhouane, Agareb 3030, Tunisia; fedia.benmefteh@gmail.com (F.B.M.); \\ ali.chenari.bouket@hotmail.com (A.C.B.); Lenka.Luptakova@uvlf.sk (L.L.); Dr-Faizah@outlook.com (F.N.A.) \\ 2 Faculty of Science, B.P. 1171, 3000, University of Sfax, Sfax 3029, Tunisia; fakher.frikha@fss.rnu.tn (F.F.); \\ amal.daoud42@gmail.com (A.D.); Neji.Gharsallah@fss.rnu.tn (N.G.) \\ 3 Department of Biology and Genetics, Institute of Biology, Zoology \& Radiobiology, \\ University of Veterinary Medicine and Pharmacy, Komenského 73, 04181 Košice, Slovakia \\ 4 Department of Environmental Technology Management, College of Life Sciences, Kuwait University, \\ P.O. Box 5969, Safat 13060, Kuwait; bader.alanzi@ku.edu.kw \\ 5 Department of Forest Protection, Forest Research Institute, 05-090 Raszyn, Poland; T.Oszako@ibles.waw.pl \\ 6 Laboratory of Soil Biology, University of Neuchatel, 2000 Neuchatel, Switzerland \\ * Correspondence: lassaad.belbahri@unine.ch; Tel.: +41-327-182-243
}

Received: 2 February 2019; Accepted: 4 March 2019; Published: 8 March 2019

check for updates

\begin{abstract}
To explore proteolytic activity of endophytic fungi inhabiting date palm roots, a Penicillium bilaiae isolate, displaying the highest level of protease production, has been recovered. Response surface methodology (RSM) was applied to optimize culture conditions for protease production by the fungus. Plackett-Burman design allowed for screening of variables effective in protease production. Results indicated that temperature, initial $\mathrm{pH}$ and glucose concentration dramatically affect protease yield. These factors were further optimized using a Box-Behnken design and RSM. A combination of initial $\mathrm{pH}(6.26)$, temperature $\left(24.5^{\circ} \mathrm{C}\right)$, glucose (13.75 g/L), $\mathrm{NaNO}_{3}(1.5 \mathrm{~g} / \mathrm{L}), \mathrm{MgSO}_{4}(0.2 \mathrm{~g} / \mathrm{L}), \mathrm{KH}_{2} \mathrm{PO}_{4}$ $(0.5 \mathrm{~g} / \mathrm{L})$ and $\mathrm{KCl}(0.5 \mathrm{~g} / \mathrm{L})$ were optimum for maximum production of protease. A 1086-fold enhancement of protease production was gained after optimization. Biochemical properties of fungal protease including the effect of $\mathrm{pH}$ and temperature on the activity and the stability of proteolytic enzyme were determined. Moreover, the influence of carbon and nitrogen sources, metal ions, detergents as well as enzyme inhibitors was investigated. Our results highlighted that protease of Penicillium bilaiae isolate TDPEF30 could be considered as a promising candidate for industrial applications.
\end{abstract}

Keywords: Endophytic fungi; Penicillium bilaiae; protease; response surface methodology; Box-Behnken

\section{Introduction}

Endophytic fungi spend the whole or a part of their life cycle colonizing the internal tissues of host plants, without causing any visible symptoms [1,2]. Therefore, they have potential to produce a broad range of valuable products with a large spectrum of biological activities and promote the growth and resistance of plants against biotic and abiotic stresses including drought, salinity and phytopathogenic 
agents $[3,4]$. Among the metabolites required for industrial and pharmaceutical usages, enzymes are currently attracting much attention [5]. There is an increasing demand for new resources of enzymes, including proteases, with various thermo-stabilities and $\mathrm{pH}$ profiles suited to different industrial requirements. Proteases are among the most important commercial enzymes used in food processing, silver recovery, diagnostics, detergent industry and pharmaceutical applications [6]. These biological catalysts account for roughly $60 \%$ to $65 \%$ of the worldwide enzyme market, which allow them to be the leader of the industrial enzymes [7]. Acid proteases among alkaline and/or neutral proteases are widely used in various food industry processes such as cheese and food processing, animal feed, and X-ray films [8].

Currently, several attempts have been made in exploration of new resources of proteases that possess desired criteria for diverse biotechnological applications. Nowadays, microorganisms represent preferred protease resources due to their susceptibility to genetic manipulation and their bioengineering potentials [9]. Moreover, microbial proteases are almost extracellular enzymes which imply that they are directly secreted into the fermentation medium without intervention of complicated extraction processes compared to plant- and animal-derived proteases [10]. Among proteases belonging to microbes, those originating from fungi are the most recommended regarding their high productivity coupled with a low materials cost. Furthermore, fungi are regarded as GRAS (Generally Recognized As Safe) organisms, with the advantage of the safety manipulation of their products, including proteases [11]. In recent years, great number of fungi has been used to produce proteases using different substrates and different approaches. Currently, the application of response surface methodology (RSM) for optimization has increased remarkably thanks to its advantages over the traditional "one-variable-at-a-time" strategy allowing gain of time and materials as well as consideration of interaction between variables to detect the true optimum [12]. The Plackett-Burman design is generally used for detection among a large number of factors as the significant ones that can be considered for further optimization. RSM is a collection of mathematical and technical approaches for searching optimum conditions, predicting the response and checking the adequacy of the model [13]. The experimental design of Box-Behnken was successfully applied in some fields of biotechnology such as the production of laccases [14], xylo-oligosaccharides [15] and wastewater treatment [16].

Despite the considerable data on the production of proteases, no attempt has been conducted on proteases originating from date palm-related endophytic fungi. The present study is therefore designed to optimize the production of protease from endophytic fungi using a statistical design. Using a newly isolated Penicillium bilaiae from the internal tissues of adult date palm tree roots, Plackett-Burman and Box Behnken designs were applied to optimize the conditions of production of a promising acid protease suitable for diverse industrial applications.

\section{Materials and Methods}

\subsection{Isolation of Endophytic Fungi from Healthy Date Palm Roots}

Endophytic fungi were isolated from internal tissues of roots of healthy date palms (variety Deglet-Ennour, Nefta, Tunisia), as described by Hallmann et al. [17]. Briefly, samples were initially washed with tap water for $30 \mathrm{~min}$ and then surface sterilized in $70 \%(v / v)$ ethanol followed by $3 \%$ $(w / v) \mathrm{NaClO}$ treatment for $3 \mathrm{~min}$. The roots were then rinsed several times with sterile distilled water and allowed to surface dry under aseptic conditions. Each root was cut into $0.5-1 \mathrm{~cm}$ pieces using a sterile scalpel. Four root pieces were, consequently, placed on plate surface containing potato dextrose agar (PDA) supplemented with $100 \mu \mathrm{g} / \mathrm{mL}$ streptomycin and incubated for 3 to 5 days at $30{ }^{\circ} \mathrm{C}$ [18]. After isolation, pure fungal cultures were obtained by sub-culturing single hyphae several times on new PDA plates. 


\subsection{Molecular Identification and Phylogenetic Analysis of the Endophytic Fungi}

Mycelial DNA was extracted from pure culture of fungi using a DNA-Easy Plant Mini kit (QIAGEN, Basel, Switzerland) according to the manufacturer's specifications. The molecular identification was carried out using the protocol described by Belbahri et al. [19]. The universal primers used for the PCR amplification of the ITS rRNA region were ITS1 (5'-TCCGTAGGTGAACCTGCGG-3') and ITS4 (5'-TCCTCCGCTTATTGATATGC- $\left.3^{\prime}\right)$ [20]. Resulting PCR products were sequenced from both sides and consensus sequences were analyzed using BLASTN available from the National Center of Biotechnology Information (NCBI) web site (http:/ / www.ncbi.nlm.nih.gov/blast/Blast.cgi). Identity of endophytic fungi was based on the percentage of homology to sequences available in the database. CLUSTAL W was used for alignment of endophytic fungal sequences and those recovered from the GenBank [21]. Distances were calculated and maximum likelihood (ML) trees were constructed using the PhyML program [22].

\subsection{Screening of Protease-Producing Endophytic Fungi on Solid Media}

The presence of protease activity was assessed using agar plates containing Czapek Dox medium supplemented with $1 \%(w / v)$ skimmed milk powder [23]. The medium was adjusted to $\mathrm{pH} 7$, and poured into plates under aseptic conditions after sterilization. Mycelia from pure culture of fungi were spot inoculated on agar plates and incubated for 5 days at $30^{\circ} \mathrm{C}$. Protease-producing strains were identified by monitoring clear zone formation around them.

\subsection{Protease Production from the Endophytic Fungus}

Protease production was carried out in $300 \mathrm{~mL}$ Erlenmeyer flasks with a working volume of $50 \mathrm{~mL}$ of Czapek Dox medium containing (g/L): $\mathrm{NaNO}_{3} 2.5 \mathrm{~g}, \mathrm{KH}_{2} \mathrm{PO}_{4} 1 \mathrm{~g}, \mathrm{MgSO}_{4} \cdot 7 \mathrm{H}_{2} \mathrm{O} 0.5 \mathrm{~g}, \mathrm{KCl}$ $0.5 \mathrm{~g}$ supplemented with $1 \%(w / v)$ glucose. The medium was sterilized at $121^{\circ} \mathrm{C}$ for $20 \mathrm{~min}$. The flasks were inoculated with $10^{6}$ spores $/ \mathrm{mL}$ and incubated on a rotary shaker at $150 \mathrm{rpm}$. Cultures were centrifuged at $8000 \times g$ for $15 \mathrm{~min}$ and the supernatant was used for determination of proteolytic activity. Experiments were performed in triplicate.

\subsection{Protease Assay}

Protease activity was measured by the method developed by Kembhavi et al. [24] using casein as a substrate: $0.5 \mathrm{~mL}$ of the enzyme, suitably diluted, was mixed with $0.5 \mathrm{~mL}$ of casein $(1 \%)(w / v)$ in $100 \mathrm{mM}$ sodium acetate buffer ( $\mathrm{pH}$ 5.5). After incubation for $10 \mathrm{~min}$ at $50{ }^{\circ} \mathrm{C}$, the reaction was stopped by adding $0.5 \mathrm{~mL}$ of TCA (trichloroacetic acid). The mixture was kept for $15 \mathrm{~min}$ at room temperature and then centrifuged at $10,000 \times g$ for $15 \mathrm{~min}$ to remove the pellet. The absorbance of the soluble fraction was finally measured at $280 \mathrm{~nm}$. A standard curve was established using tyrosine solutions $(0-50 \mathrm{mg} / \mathrm{L})$. One unit of protease activity was defined as the amount of enzyme that releases $1 \mu \mathrm{mol}$ of tyrosine per minute according to standard curve.

\subsection{Experimental Designs}

\subsubsection{Plackett-Burman Design}

The independent variables of protease production were initial $\mathrm{pH}$, temperature, $\mathrm{MgSO}_{4}, \mathrm{NaNO}_{3}$, $\mathrm{KH}_{2} \mathrm{PO}_{4}, \mathrm{KCl}$ and glucose. These variables were selected from a preliminary literature review. A Plackett-Burman design was used for multifactor rapid screening to find the most significant independent factors [25-28]. Then, the seven factors were investigated using the Plackett-Burman design with a first-order polynomial equation. Each factor was examined at low $(-1)$ and high (+1) levels. Eleven variables (including 4 dummy variables) were screened in 15 experimental runs, as shown in Table 1. The fitted first-order model is:

$$
Y=\beta_{0}+\sum \beta_{\mathrm{i}} x_{\mathrm{i}}
$$


$Y$ is the predicted response, $\beta_{0}$ and $\beta_{\mathrm{i}}$ are constant coefficients and $x_{\mathrm{i}}$ is the coded independent factors.

Table 1. Plackett-Burman design for screening of significant factors affecting the protease production by Penicillium bilaiae.

\begin{tabular}{ccccccccc}
\hline Run & $\begin{array}{c}\text { Initial } \\
\mathbf{p H}\end{array}$ & $\begin{array}{c}\text { Temperature } \\
\left({ }^{\circ} \mathbf{C}\right)\end{array}$ & $\begin{array}{c}\mathbf{M g S O}_{4} \\
(\mathbf{g} / \mathbf{L})\end{array}$ & $\begin{array}{c}\mathbf{N a N O}_{3} \\
(\mathbf{g} / \mathbf{L})\end{array}$ & $\begin{array}{c}\mathbf{K H}_{2} \mathbf{P O}_{4} \\
(\mathbf{g} / \mathbf{L})\end{array}$ & $\begin{array}{c}\mathbf{K C l} \\
(\mathbf{g} / \mathrm{L})\end{array}$ & $\begin{array}{c}\mathrm{Glucose} \\
(\mathbf{g} / \mathbf{L})\end{array}$ & $\begin{array}{c}\text { Response } \\
(\mathbf{U} / \mathbf{m L})\end{array}$ \\
\hline 1 & 8 & 40 & 0.2 & 3.5 & 1.5 & 1.5 & 8 & 56.56 \\
\hline 2 & 4 & 40 & 0.8 & 1.5 & 1.5 & 1.5 & 14 & 35.40 \\
\hline 3 & 8 & 20 & 0.8 & 3.5 & 0.5 & 1.5 & 14 & 62.07 \\
\hline 4 & 4 & 40 & 0.2 & 3.5 & 1.5 & 0.5 & 14 & 38.93 \\
\hline 5 & 4 & 20 & 0.8 & 1.5 & 1.5 & 1.5 & 8 & 53.81 \\
\hline 6 & 4 & 20 & 0.2 & 3.5 & 0.5 & 1.5 & 14 & 77.83 \\
\hline 7 & 8 & 20 & 0.2 & 1.5 & 1.5 & 0.5 & 14 & 21.16 \\
\hline 8 & 8 & 40 & 0.2 & 1.5 & 0.5 & 1.5 & 8 & 83.58 \\
\hline 9 & 8 & 40 & 0.8 & 1.5 & 0.5 & 0.5 & 14 & 57.62 \\
\hline 10 & 4 & 40 & 0.8 & 3.5 & 0.5 & 0.5 & 8 & 41.82 \\
\hline 11 & 8 & 20 & 0.8 & 3.5 & 1.5 & 0.5 & 8 & 186.21 \\
\hline 12 & 4 & 20 & 0.2 & 1.5 & 0.5 & 0.5 & 8 & 59.60 \\
\hline 13 & 6 & 30 & 0.5 & 2.5 & 1 & 1 & 11 & 53.88 \\
\hline 14 & 6 & 30 & 0.5 & 2.5 & 1 & 1 & 11 & 43.73 \\
\hline 15 & 6 & 30 & 0.5 & 2.5 & 1 & 1 & 11 & 50.22 \\
\hline
\end{tabular}

\subsubsection{Box-Behnken Design and Response Surface Analysis}

The Box-Behnken design (BBD) of RSM was employed to optimize the three most significant factors (temperature, glucose concentration and initial $\mathrm{pH}$ ) for enhancing protease production from Penicillium bilaiae, screened by Plackett-Burman design [29]. The three independent factors were investigated at three levels $(-1,0,1)$ and the experimental design used for study is shown in Table 2 . The protease production was fitted using a second order polynomial equation and multiple regression of the data was carried out for obtaining an empirical model related to the most significant factors. The general form of the second-order polynomial equation is:

$$
Y=\beta_{0}+\Sigma \beta_{\mathrm{i}} x_{\mathrm{i}}+\Sigma \beta_{\mathrm{ii}} x_{\mathrm{i}}^{2}+\Sigma \beta_{\mathrm{ij}} x_{\mathrm{i}} x_{\mathrm{j}}
$$

where $Y$ is the predicted response, $x_{\mathrm{i}}$ and $x_{\mathrm{j}}$ are independent factors, $\beta_{0}$ is the model intercept, $\beta_{\mathrm{i}}$ is the linear coefficient, $\beta_{\mathrm{ii}}$ is the quadratic coefficient and $\beta_{\mathrm{ij}}$ is the interaction coefficient.

Table 2. Levels of variables tested in Box Behnken Design (BBD) for optimization of protease production.

\begin{tabular}{cccc}
\hline \multirow{2}{*}{ Factor } & \multicolumn{3}{c}{ Range and Levels } \\
\cline { 2 - 4 } & $\mathbf{- 1}$ & $\mathbf{0}$ & $\mathbf{1}$ \\
\hline$X_{1}$ Temperature $\left({ }^{\circ} \mathrm{C}\right)$ & 20 & 30 & 40 \\
\hline$X_{2}$ Glucose $(\mathrm{g} / \mathrm{L})$ & 8 & 11 & 14 \\
\hline$X_{3} \mathrm{pH}$ & 4 & 6 & 8 \\
\hline
\end{tabular}

\subsection{Data Analysis and Software}

Design Expert 7.0.0 (trial version, Stat Ease Inc., Minneapolis, MN, USA) was used for experimental design and regression analysis of the experimental data. Analysis of variance (ANOVA) was employed to estimate the statistical parameters. 


\subsection{Effect of Carbon and Nitrogen Sources on Proteolytic Activity}

Different sources of carbon and nitrogen were examined for their effect on the production of protease from the endophytic fungus. In total, eight sources of carbon including starch, galactose, sucrose, dextrose, fructose, mannose, xylose and maltose and seven of simple and complex nitrogen sources including casein peptone, ammonium sulfate, urea, casein, yeast extract, $\mathrm{KNO}_{3}$ and malt extract were investigated on the basis of the $\mathrm{C} / \mathrm{N}$ ratio. The medium amended with glucose and $\mathrm{NaNO}_{3}$ as sources of carbon and nitrogen, respectively, was considered as control.

\subsection{Effect of $\mathrm{pH}$ and Temperature on Enzyme Activity and Stability}

Both optimal $\mathrm{pH}$ and stability of proteolytic activity at different $\mathrm{pH}$ values were studied. For the determination of optimum $\mathrm{pH}$, the enzyme preparation was experimented at various $\mathrm{pH}$ values (3-9) using casein $(1 \%)$ as a substrate. The $\mathrm{pH}$ stability experiments were conducted after pre-incubation of protease containing supernatant in different buffers for $1 \mathrm{~h}$ at optimum temperature $\left(25^{\circ} \mathrm{C}\right)$. The following buffers were used: $100 \mathrm{mM}$ glycine- $\mathrm{HCl}$ for $\mathrm{pH} 3,100 \mathrm{mM}$ sodium acetate for $\mathrm{pH} 4-6$, Tris- $\mathrm{HCl}$ for $\mathrm{pH} 6-8$, glycine- $\mathrm{NaOH}$ for $\mathrm{pH}$ 9. The remaining activity tests were assessed under standard assay conditions.

The optimum temperature for proteolytic activity was evaluated at $\mathrm{pH} 6$ using protease assay at different temperatures values $\left(10-100{ }^{\circ} \mathrm{C}\right)$. The effect of temperature on the stability of the protease was assessed by pre-incubating the aliquots at different temperatures for a fixed time. Afterwards, the residual proteolytic activity was determined using casein as a substrate. The unheated crude enzyme was considered as control.

\subsection{Effect of Metal Ions, Detergents and Enzyme Inhibitors on Proteolytic Activity}

The effect of metal ions was investigated by measuring the residual activity after addition of $5 \mathrm{mM}$ of $\mathrm{CuSO}_{4}, \mathrm{CaCl}_{2}, \mathrm{FeSO}_{4}, \mathrm{ZnSO}_{4}, \mathrm{MnCl}_{2}, \mathrm{HgCl}_{2}, \mathrm{H}_{3} \mathrm{BO}_{4}$ and $\mathrm{NaCl}$. In addition, triton X-100, tween 80 and 3-[(3-cholamidopropyl) dimethylammonio]-1-propane sulfonate (CHAPS) were added separately to the production medium at a rate of $0.1 \%$ to evaluate their effect on enzyme activity. In order to study the effect of inhibitors such as $\beta$-mercaptoethanol, ethylene diamine tetra-acetic acid (EDTA), phenylmethylsulfonyl fluoride (PMSF) and dithiothreitol (DTT) at a rate of $1 \mathrm{mM}$, the enzyme preparations were pre-incubated with each inhibitor for $1 \mathrm{~h}$ at $4{ }^{\circ} \mathrm{C}$ before determination of proteolytic activity. The aliquots without any additive were considered as the $100 \%$ control.

\section{Results}

\subsection{Screening for Proteolytic Activity and Molecular Identification of Penicillium bilaiae TDPEF30}

In order to explore proteolytic activity of endophytic fungi from date palm roots, a total of 21 fungi were recovered from the internal tissues of adult date palm trees healthy roots (Phoenix dactylifera L., Deglet Ennour variety). Recovered fungal isolates were screened on solid medium for their ability to produce proteolytic enzymes (data not shown). Isolate TDPEF30 displayed the highest level of production of protease revealing a halo diameter in the range of $30 \pm 0.5 \mathrm{~mm}$. Internal Transcribed Spacer (ITS) regions of fungal rDNA were amplified and sequenced. The identity of isolates was determined based on homology with sequences available in the BLASTN database. TDPEF30 showed high homology to Penicillium bilaiae sequences available in the database. Phylogenetic analysis was conducted to ascertain the phylogenetic position and the taxonomy of TDPEF30. As indicated in Figure 1, TDPEF30 lies within Penicillium bilaiae isolates with high bootstrap value. Therefore, it has been definitely identified as Penicillium bilaiae. 


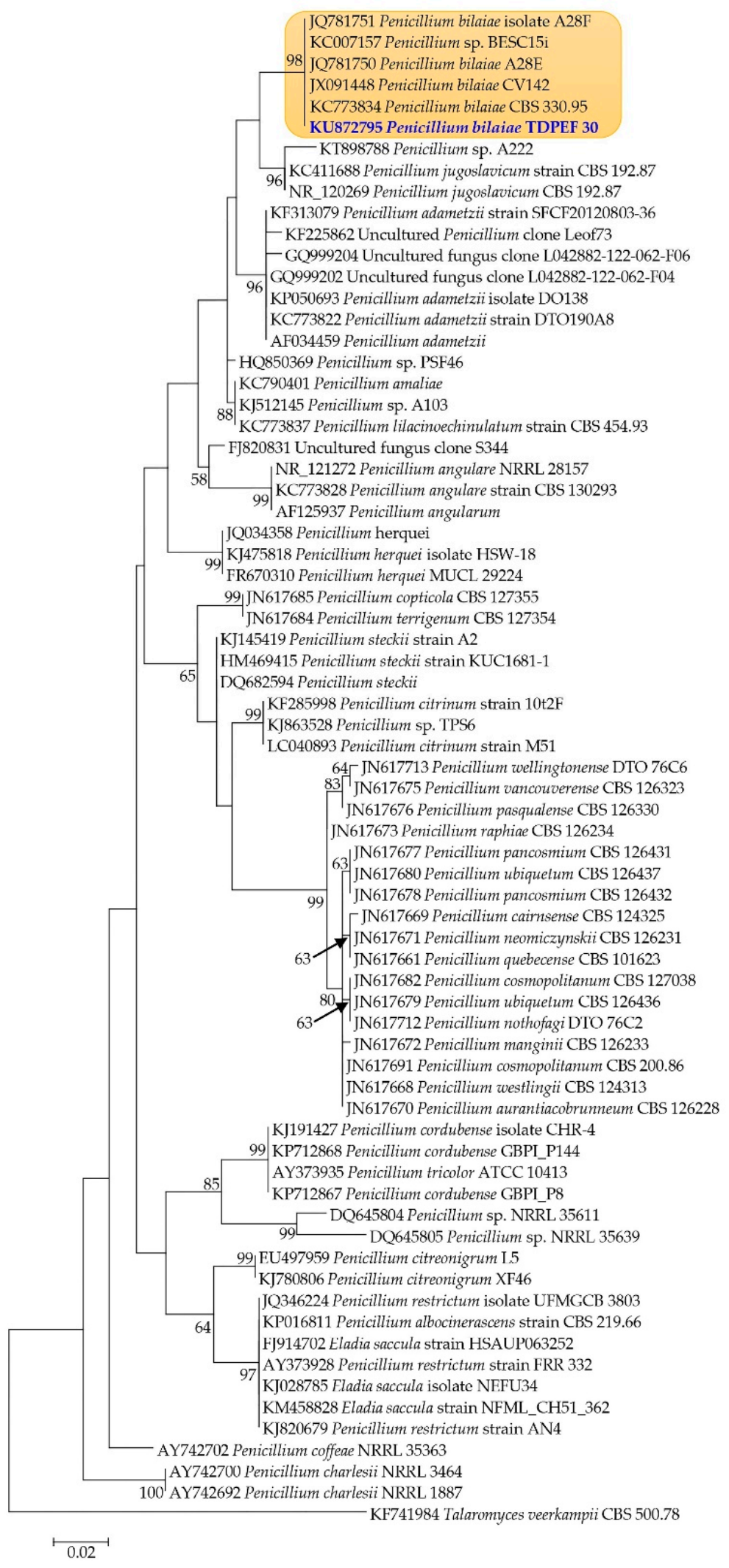

Figure 1. Phylogenetic tree based on $18 \mathrm{~S}$ rRNA sequence highlighting the phylogenetic position of Penicillium bilaiae TDPEF30 within closely related Penicillium spp. Talaromyces veerkampii (CBS 500.78, KF741984) was used as an outgroup. Bootstrap values are expressed as percentage of 1000 replicates. 


\subsection{Experimental Designs}

\subsubsection{Plackett-Burman Design}

The Plackett-Burman design was used for screening of the significant factors that affect TDPEF30 protease production. Fifteen experiments were carried out to evaluate the effect of seven factors on the protease production and the results are shown in Table 1. A $t$-test and Fisher's test were used to identify the significance of each factor on the protease production. Statistical analysis of the response was performed (Table 3). According to the design, variables that have the greatest effect on the production of protease from Penicillium bilaiae were glucose concentration, $\mathrm{pH}$ and temperature at $95 \%$ confidence level. However, $\mathrm{pH}$ and the concentration of glucose have positive effects while 4 variables including $\mathrm{MgSO}_{4}, \mathrm{NaNO}_{3}, \mathrm{KH}_{2} \mathrm{PO}_{4}$ and $\mathrm{KCl}$ concentration have negative effects on the proteolytic activity. Only temperature was found to be significantn in influencing protease activity, as shown in Table 3 (Prob $>F<0.05)$. Non-significant variables with negative effect $\left(\mathrm{MgSO}_{4}, \mathrm{NaNO}_{3}, \mathrm{KH}_{2} \mathrm{PO}_{4}\right.$ and $\mathrm{KCl}$ concentrations) were fixed to their low levels corresponding to $0.2,1.5,0.5$ and $0.5 \mathrm{~g} / \mathrm{L}$, respectively. Although glucose concentration and initial $\mathrm{pH}$ were not significant at $95 \%$ confidence level, they were selected with the temperature for further optimization to obtain a maximal response.

\subsubsection{Box Behnken Design (BBD) and Response Surface Analysis}

A response surface design was further applied when the optimal region for running the process has been identified $[27,28,30]$. Based on the Placket-Burman design output, an RSM using the Box Behnken design was applied to determine the optimal levels of the three selected variables (temperature, glucose and initial $\mathrm{pH}$ ). The respective low and high levels with the coded levels for the three variables are defined in Table 3. A total of 15 experiments with different combinations of the selected parameters were performed. The observed and predicted responses are reported in Table 4. The experimental results were analyzed by standard ANOVA and the BBD was fitted with the second-order polynomial equation:

$$
\operatorname{Ln}(\hat{Y})=5.798-2.194 X_{1}+0.157 X_{2}-0.101 X_{3}-0.565 X_{1} X_{3}-2.305 X_{1}^{2}+0.428 X_{2}^{2}-0.416 X_{3}^{2}
$$

where $X_{1}, X_{2}$ and $X_{3}$ correspond to temperature, glucose concentration and $\mathrm{pH}$, respectively.

Table 3. Determination of significant variables for production of protease by the endophytic fungus Penicillium bilaiae using Plackett-Burman Design.

\begin{tabular}{|c|c|c|c|c|c|c|c|}
\hline Source & Sum of Squares & df & Mean of Square & $F$-Value & Prob $>F$ & Contribution & \\
\hline Model & 9385.037 & 7 & 1340.720 & 4.345 & 0.047 & $\%$ & Effect \\
\hline A-pH & 673.051 & 1 & 673.051 & 2.181 & 0.190 & 4.24 & 14.98 \\
\hline B-Temperature & 6325.480 & 1 & 6325.480 & 20.499 & 0.004 & 39.81 & -45.92 \\
\hline $\mathrm{C}-\mathrm{MgSO}_{4}$ & 302.304 & 1 & 302.304 & 0.980 & 0.361 & 1.90 & -10.04 \\
\hline $\mathrm{D}-\mathrm{NaNO}_{3}$ & 75.350 & 1 & 75.350 & 0.244 & 0.639 & 0.47 & -5.01 \\
\hline $\mathrm{E}-\mathrm{KH}_{2} \mathrm{PO}_{4}$ & 229.425 & 1 & 229.425 & 0.744 & 0.422 & 1.44 & -8.75 \\
\hline $\mathrm{F}-\mathrm{KCl}$ & 50.225 & 1 & 50.225 & 0.163 & 0.701 & 0.32 & -4.09 \\
\hline G-Glucose & 1729.200 & 1 & 1729.200 & 5.604 & 0.056 & 10.88 & 24.01 \\
\hline
\end{tabular}


Table 4. Box Behnken matrix and response results for optimization of protease.

\begin{tabular}{cccccc}
\hline \multirow{2}{*}{ Run } & \multicolumn{3}{c}{ Factors } & \multicolumn{2}{c}{ Protease Activity U/mL } \\
\cline { 2 - 6 } & $\left.\boldsymbol{X}_{\mathbf{1}}{ }^{\circ}{ }^{\circ} \mathbf{C}\right)$ & $\boldsymbol{X}_{\mathbf{2}}(\mathbf{g} / \mathrm{L})$ & $\boldsymbol{X}_{\mathbf{3}}$ & Experimental & Predicted \\
\hline 1 & -1 & -1 & 0 & 417.57 & 386.82 \\
\hline 2 & 1 & -1 & 0 & 6.20 & 4.80 \\
\hline 3 & -1 & 1 & 0 & 328.69 & 529.61 \\
\hline 4 & 1 & 1 & 0 & 7.61 & 6.58 \\
\hline 5 & -1 & 0 & -1 & 144.73 & 122.41 \\
\hline 6 & 1 & 0 & -1 & 3.73 & 4.71 \\
\hline 7 & -1 & 0 & 1 & 390.76 & 309.52 \\
\hline 8 & 1 & 0 & 1 & 1.05 & 1.24 \\
\hline 9 & 0 & -1 & -1 & 329.40 & 315.42 \\
\hline 10 & 0 & 1 & -1 & 441.55 & 431.85 \\
\hline 11 & 0 & -1 & 1 & 177.04 & 257.53 \\
\hline 12 & 0 & 1 & 1 & 480.34 & 352.59 \\
\hline 13 & 0 & 0 & 0 & 398.52 & 329.56 \\
\hline 14 & 0 & 0 & 0 & 292.72 & 329.56 \\
\hline 15 & 0 & 0 & 0 & 306.83 & 329.56 \\
\hline
\end{tabular}

\subsubsection{Analysis of Variance and Validation of the Model}

Statistical significance of the model equation was evaluated by the $F$-test for ANOVA. As shown in Table 5, the regression sum of squares was statistically significant when the $F$-test used was at $95 \%$ probability level, suggesting that the variation considered by the model was significantly greater than the unexplained variation. The two checkpoint results were employed to validate the fitted model (Table 6). The measured values $\left(y_{\mathrm{i}}\right)$ were very close to those calculated $(\hat{y})$ using the model equation (Table 7). Moreover, the differences between calculated and measured responses were not significant ( $t$ test, $p>0.05$ ). It was, therefore, concluded that the model was adequate in describing the response surfaces, and could be used as a prediction equation in the design space.

Table 5. Analysis of variance for surface response.

\begin{tabular}{|c|c|c|c|c|c|}
\hline Source of Variation & Sum of Squares & $\mathrm{df}$ & Mean of Square & $F$ Value & $p$ Value Prob $>\mathrm{F}$ \\
\hline Regression & 61.34 & 7 & 8.76 & 78.84 & $<0.0001 *$ \\
\hline Residual & 0.78 & 7 & 0.11 & & \\
\hline Cor Total & 62.12 & 14 & & & \\
\hline
\end{tabular}

Table 6. Experimental condition of the check-points.

\begin{tabular}{cccccc}
\hline \multirow{2}{*}{ Run } & \multicolumn{3}{c}{ Variables Values } & \multicolumn{2}{c}{ Response $(\mathrm{U} / \mathrm{mL})$} \\
\cline { 2 - 5 } & $\boldsymbol{X}_{\mathbf{1}}\left({ }^{\circ} \mathrm{C}\right)$ & $\boldsymbol{X}_{\mathbf{2}}(\mathrm{g} / \mathrm{L})$ & $\boldsymbol{X}_{\mathbf{3}}$ & Experimental & Predicted \\
\hline 1 & 24.46 & 13.75 & 6.26 & 1086.95 & 924.23 \\
\hline 2 & 24.09 & 13.78 & 5.59 & 744.85 & 842.16 \\
\hline \multicolumn{3}{c}{$X_{1}$ temperature, $X_{2}$ glucose concentration, $X_{3}$ initial $\mathrm{pH}}$.
\end{tabular}


Table 7. Validation of the model with the check-points.

\begin{tabular}{ccccccc}
\hline Run & $y_{\mathbf{i}}$ & $\hat{y}_{\mathrm{i}}$ & $\begin{array}{c}\text { Residual } \\
e=y_{\mathrm{i}}-\hat{y}_{\mathrm{i}}\end{array}$ & t.exp. & $\begin{array}{c}\text { Laverage } \\
\text { (dU) }\end{array}$ & Signif.\% \\
\hline 6.991 & 6.830 & 0.161 & 0.437 & 0.224 & 67.50 \\
\hline 6.613 & 6.737 & $-0,124$ & $-0,335$ & 0.235 & 74.72 \\
\hline \multicolumn{6}{c}{$y_{\mathrm{i}}=\operatorname{Ln}(Y \exp .) ; \hat{y}_{\mathrm{i}}=\operatorname{Ln}\left(Y_{\text {calc. }}\right)}$.
\end{tabular}

\subsubsection{Graphical Interpretation of the Response Surface Model}

The protease production was a function of the interaction between the three variables (glucose concentration, $\mathrm{pH}$ and temperature). The response surface curves were plotted to explain the interaction of the variables and to determine the optimum level of each variable for maximum response. The response surface curves are shown in Figure 2. Each figure demonstrates the effect of two factors while the other factors were fixed at zero level. The effect of temperature and glucose on the protease production at a fixed $\mathrm{pH}$ of 6 is shown in Figure 2A. Decreasing the temperature led to an increase in the protease production, irrespective of the glucose concentration. The response value reached its highest point at $25^{\circ} \mathrm{C}$.

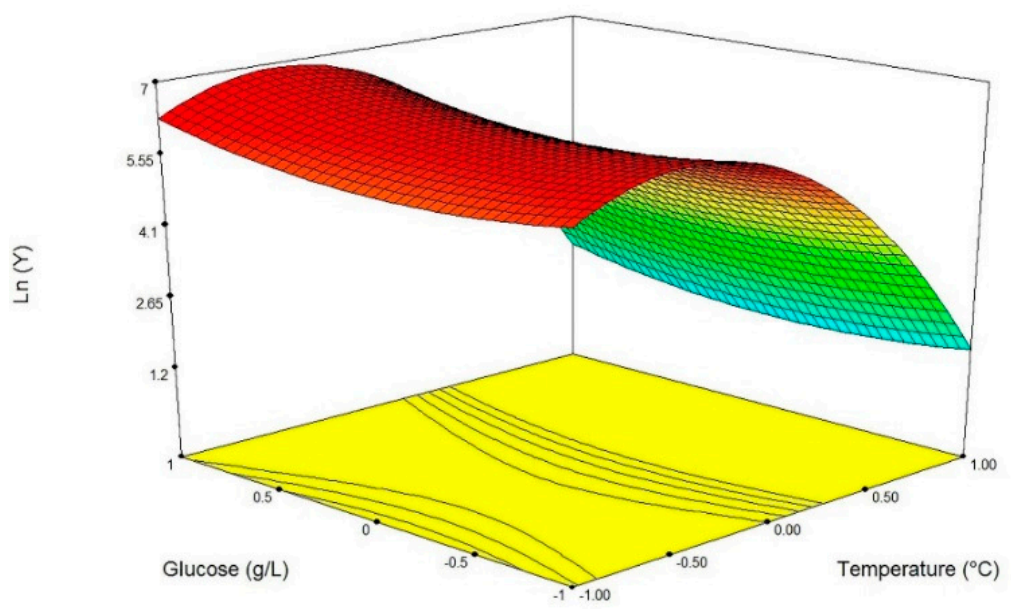

A

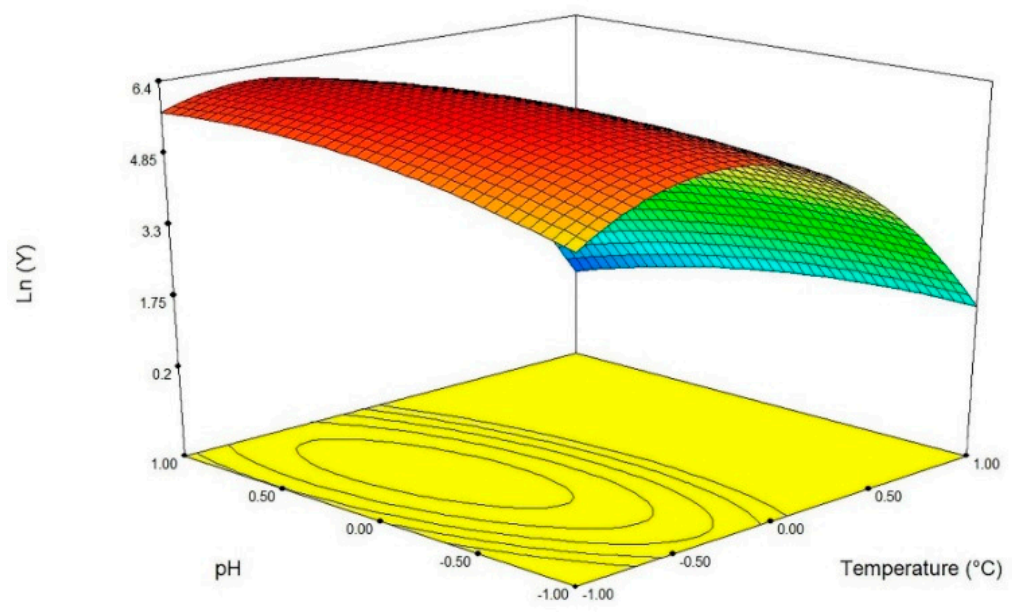

B

Figure 2. Cont. 


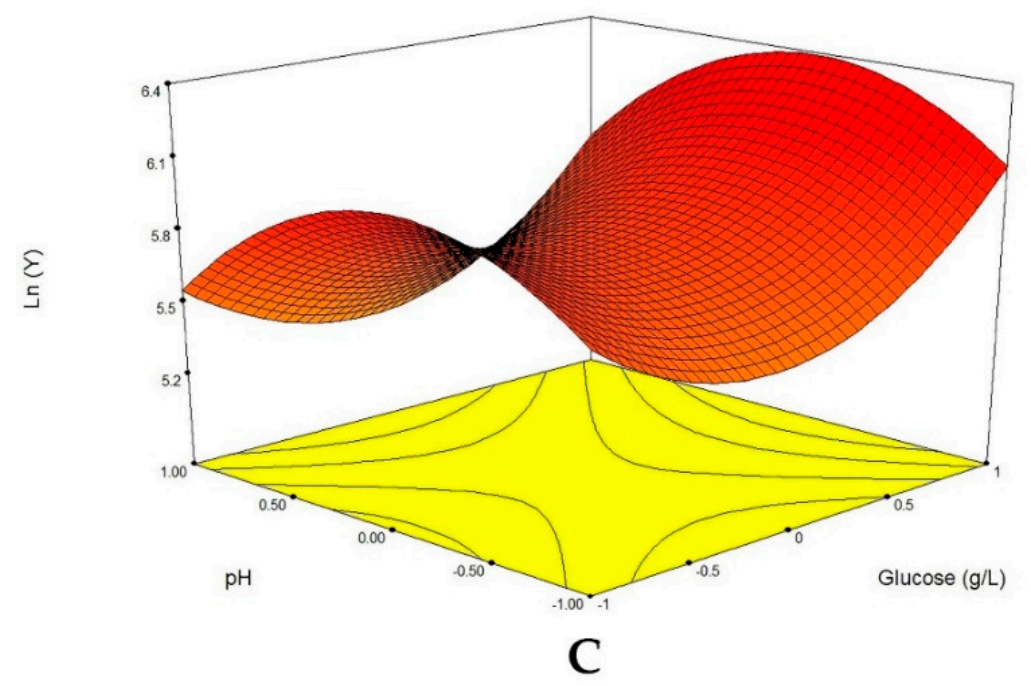

Figure 2. Response surface of protease production from the endophytic fungus Penicillium bilaiae showing the interactive effects of the temperature versus glucose concentration (A); culture $\mathrm{pH}$ versus temperature and glucose (B); concentration versus initial $\mathrm{pH}(\mathbf{C})$.

However, at $25^{\circ} \mathrm{C}$, the glucose concentration had no significant impact on the protease production. The effect of temperature and $\mathrm{pH}$ on the protease production at a fixed glucose concentration of $11 \mathrm{~g} / \mathrm{L}$ is presented in Figure 2B. The response value reached its highest point at $25^{\circ} \mathrm{C}$ and $\mathrm{pH} 6$. The protease production slightly increases when the $\mathrm{pH}$ is equal to 6 . Figure $2 \mathrm{C}$ shows the effect of glucose concentration and the $\mathrm{pH}$ on the protease production at a fixed temperature of $30^{\circ} \mathrm{C}$. Increasing the concentration of glucose resulted in an increase in the response surface. The response value reached its highest point at $14 \mathrm{~g} / \mathrm{L}$ of glucose concentration and $\mathrm{pH} 6$. Furthermore, the elliptical contour in Figure $2 \mathrm{~B}$ indicates that an elevation in initial $\mathrm{pH}$ as well as the temperature had positive effects on protease activity, while, an increase in the above constituents was found to have negative influence on the protease production from the date palm endophytic fungus (Figure 2A,C). From the surface response graphs and the regression analysis of Equation (3), it could be concluded that the optimal conditions for protease production were located in the region where temperature, initial $\mathrm{pH}$ and glucose concentration are in the range of $25^{\circ} \mathrm{C}, 6$ and $14 \mathrm{~g} / \mathrm{L}$, respectively.

\subsubsection{Effect of Carbon and Nitrogen Sources on Protease Production}

A series of experiments were performed to study the effects of various carbon and nitrogen sources on protease production by Penicillium bilaiae TDPEF30. Cultures were conducted in flasks containing Czapek Dox medium with respect to the $\mathrm{C} / \mathrm{N}$ ratio. Results are presented in Figure 3 . Among the different sources of examined carbon, maximum protease production was attained in the presence of easily assimilated compounds. Mannose was the best source of carbon for the production of protease $(1907.28 \mathrm{U} / \mathrm{mL})$ followed by a complex source of carbon including sucrose $(1649.12 \mathrm{U} / \mathrm{mL})$ and fructose $(1060.15 \mathrm{U} / \mathrm{mL})$, as shown in Figure 3A.

Both organic and inorganic sources of nitrogen (yeast extract, ammonium sulfate, casein, casein peptone, $\mathrm{KNO}_{3}$, urea, malt extract) were added separately to the culture medium to evaluate their influence on protease production. Results reported in Figure 3B clearly indicate that the highest level of protease production was obtained with malt extract $(1433.28 \mathrm{U} / \mathrm{mL})$ followed by $\mathrm{KNO}_{3}$ $(1247.07 \mathrm{U} / \mathrm{mL})$. Among the various sources of carbon and nitrogen tested, mannose and malt extract were found to be the most suitable substrates for the protease production from the endophytic fungus Penicillium bilaiae TDPEF30. 


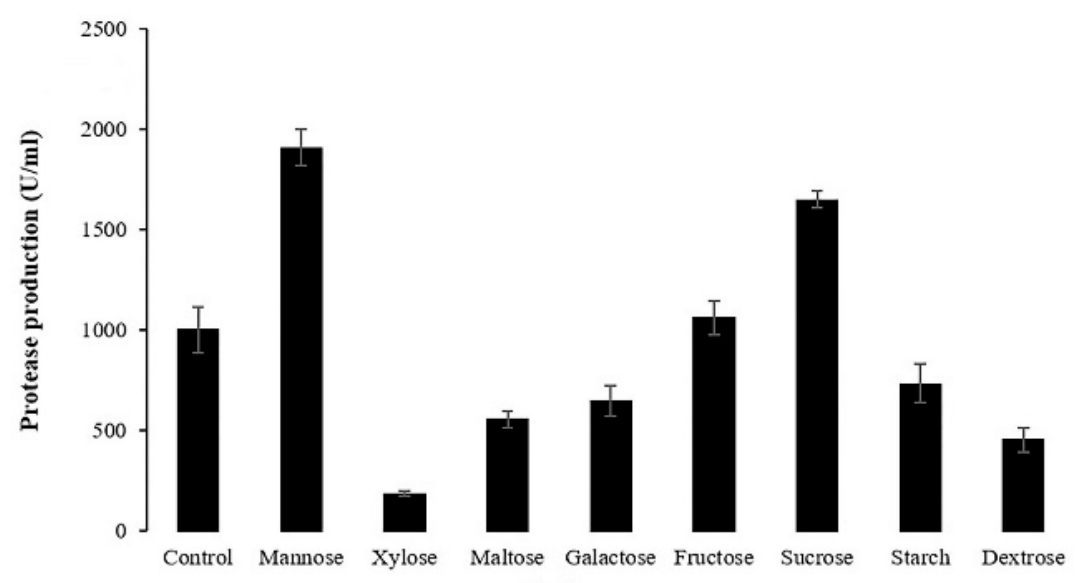
Carbon sources

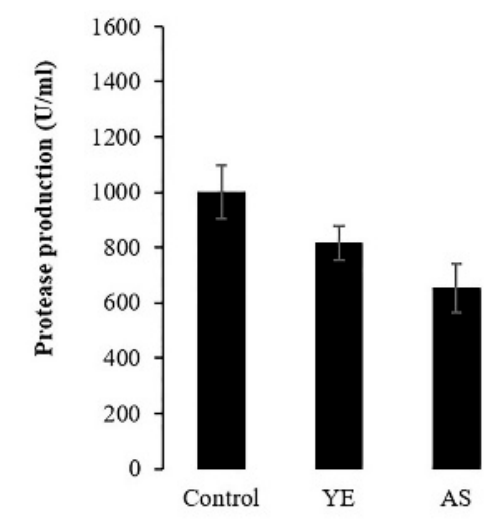

A

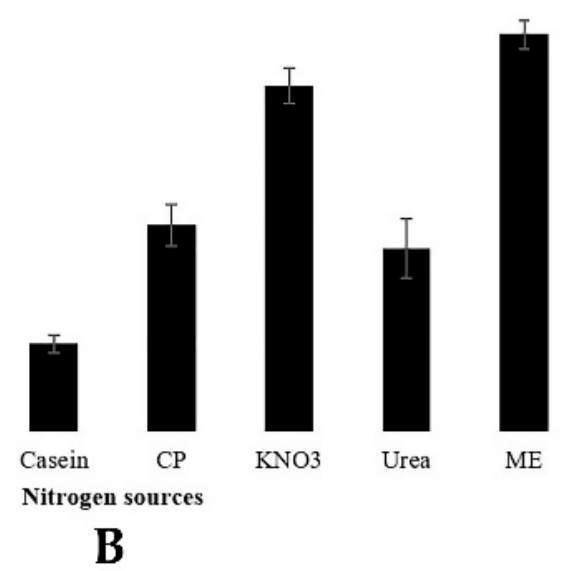

Figure 3. Effect of various sources of carbon (A) and nitrogen $(B)$ on protease production using $\mathrm{C} / \mathrm{N}$ ratio. YE yeast extract, AS ammonium sulfate, $\mathrm{CP}$ casein peptone, ME malt extract.

\subsubsection{Effect of $\mathrm{pH}$ and temperature on protease activity and stability}

The effect of $\mathrm{pH}$ on protease activity was determined over a $\mathrm{pH}$ range of 3-9 using different buffer solutions. As shown in Figure 4A, maximum protease activity was observed at $\mathrm{pH}$ 6, which indicated the acidity of the proteolytic enzyme produced by the endophytic fungus associated with adult date palm trees. The proteolytic enzyme was active at $\mathrm{pH} 8$ since the relative activity at $\mathrm{pH} 8$ was about $50 \%$ of that observed at $\mathrm{pH} 6$. Proteases were totally inactivated at $\mathrm{pH} 9$ and 10.

The stability of proteolytic enzymes was evaluated after incubation of enzyme preparation in different buffers with various $\mathrm{pH}$ values at $4{ }^{\circ} \mathrm{C}$ for $1 \mathrm{~h}$. The results are reported in Figure 4B. Proteases were more stable $(>50 \%)$ under acidic conditions $(\mathrm{pH} 5-6.5)$. The stability decreased at neutral $\mathrm{pH}$ and increased slightly at $\mathrm{pH}$ 8. The fungal protease was more stable at $\mathrm{pH}$ range of $5.5-6.5$, as shown in Figure 4B. 


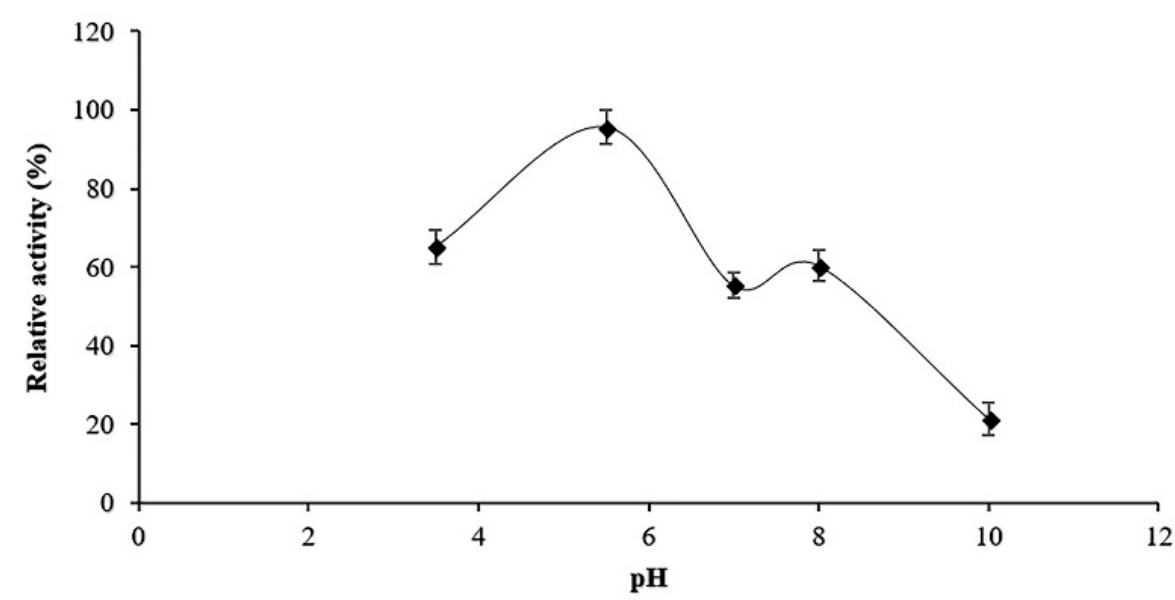

A

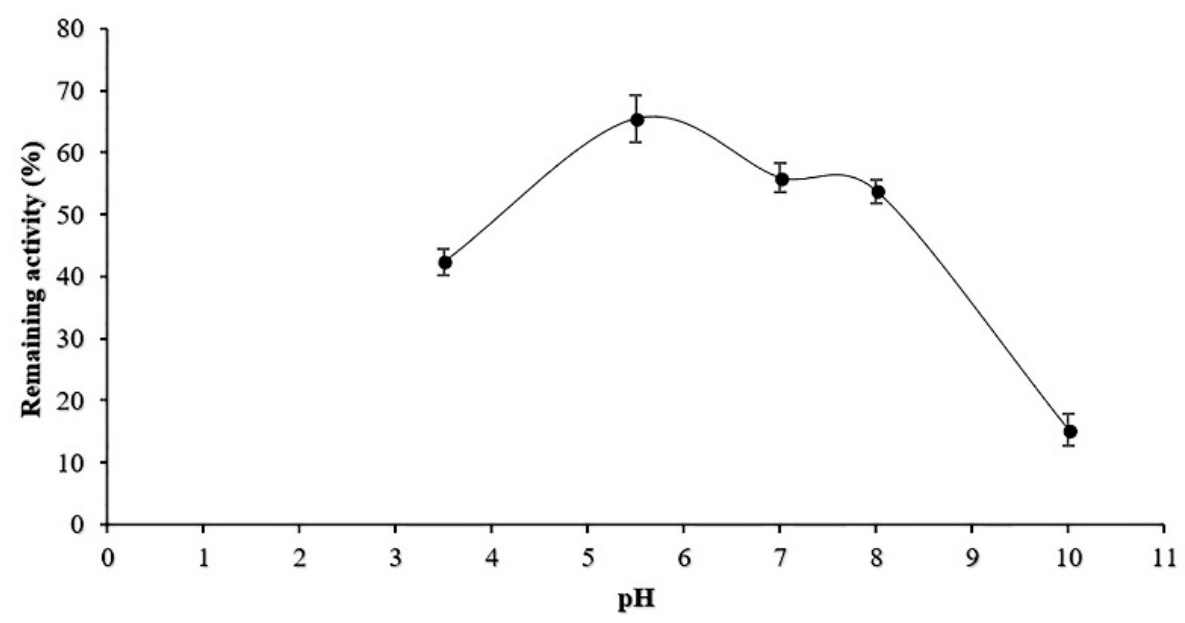

B

Figure 4. Effect of $\mathrm{pH}$ on the activity (A) and the stability (B) of the proteolytic enzymes of Penicillium bilaiae.

Proteolytic enzyme activity of the endophytic fungus Penicillium bilaiae TDPEF30 was measured at temperatures ranging from 10 to $100{ }^{\circ} \mathrm{C}$. The relative and the residual activities were determined (Figure 5). The proteolytic activity showed that the enzyme maintained more than $50 \%$ of its activity over a range of $20-50{ }^{\circ} \mathrm{C}$ with optimum activity at $25^{\circ} \mathrm{C}$ using casein as a substrate (Figure 5A).

The effect of temperature on protease stability was evaluated after incubation of crude supernatant at different temperatures ranging from 20 to $70{ }^{\circ} \mathrm{C}$ and $\mathrm{pH} 6$ for various incubation periods. As shown in Figure 5B, the enzyme was highly stable at $25{ }^{\circ} \mathrm{C}$. The protease was able to retain $100 \%$ of its activity at $25^{\circ} \mathrm{C}$ even after $2 \mathrm{~h}$ of incubation while it was inactivated by losing $90 \%$ of its initial activity after 10 min of incubation at $70^{\circ} \mathrm{C}$. 


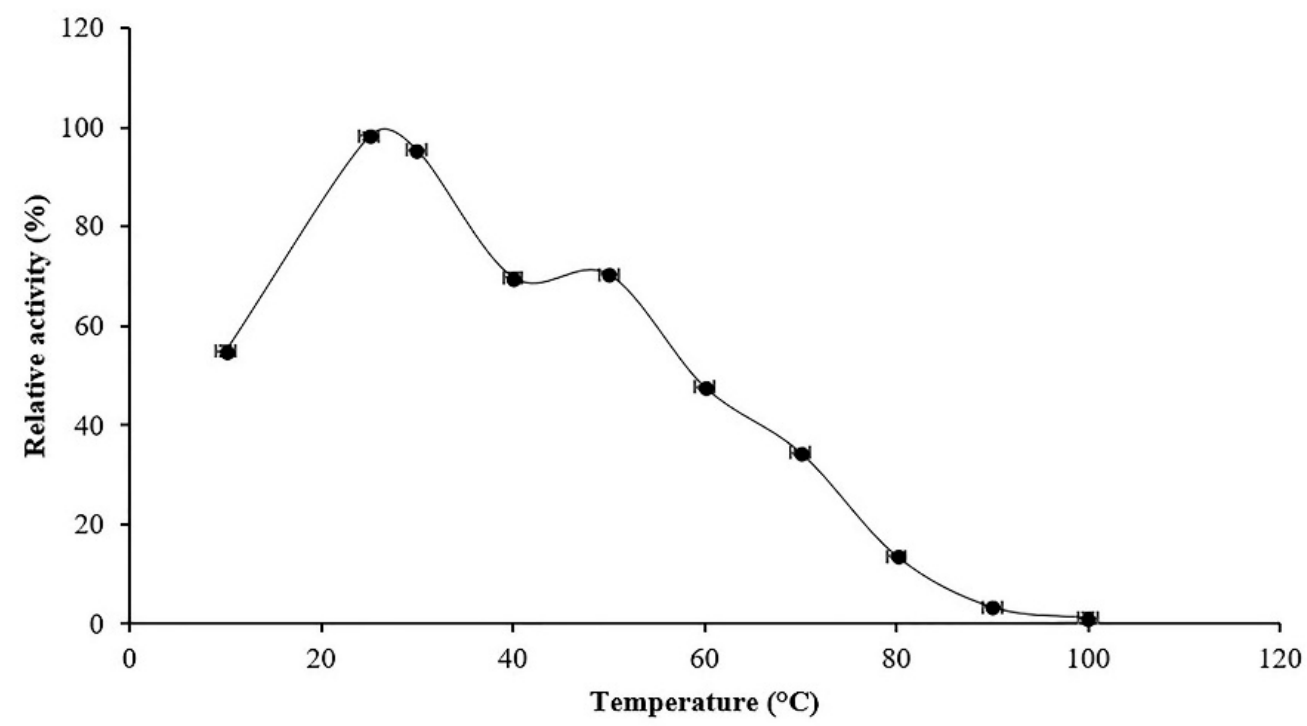

A

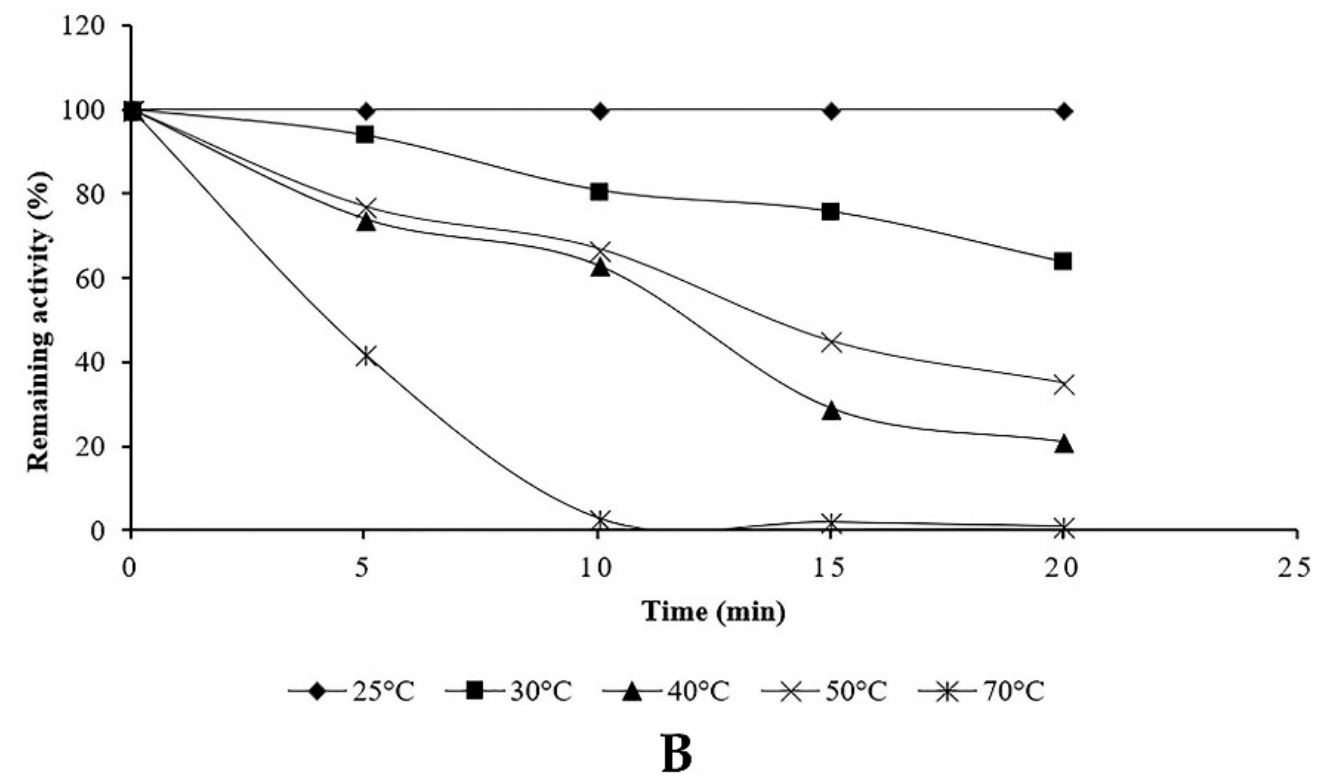

Figure 5. Effect of temperature on the activity (A) and the stability (B) of proteolytic enzyme of Penicillium bilaiae.

\subsubsection{Effect of Metal Ions, Detergents and Enzyme Inhibitors on Proteolytic Activity}

The influence of metal ions such as $\mathrm{Cu}^{2+}, \mathrm{Ca}^{2+}, \mathrm{Fe}^{2+}, \mathrm{Zn}^{2+}, \mathrm{Mn}^{2+}, \mathrm{Hg}^{2+}, \mathrm{B}^{3+}$ and $\mathrm{Na}^{2+}(5 \mathrm{mM})$, detergents $(0.1 \%)$, namely, tween 80 , CHAPS and triton X-100 as well as enzyme inhibitors $(5 \mathrm{mM})$ $\beta$-mercaptoethanol, DTT, EDTA and PMSF were tested at $\mathrm{pH} 6$ and $25^{\circ} \mathrm{C}$ on protease activity from the endophytic fungus Penicillium bilaiae TDPEF30. The results are reported in Table 8. Concerning the effect of metal ions, the relative activity was measured after addition of $5 \mathrm{mM}$ of the respective ion to the reaction mixture. According to Table 7, the addition of $\mathrm{Mn}^{2+}, \mathrm{B}^{3+}$ enhanced the proteolytic activity by 114 and $191 \%$, respectively, while $\mathrm{Cu}^{2+}, \mathrm{Ca}^{2+}, \mathrm{Fe}^{2+}$ and $\mathrm{Hg}^{2+}$ inhibited the enzyme activity to approximately $14-54 \%$. Furthermore, $\mathrm{Zn}^{2+}$ and $\mathrm{Na}^{2+}$ had no effect on protease activity.

The effect of detergents on the production of protease from the endophytic fungus Penicillium bilaiae TDPEF30 was also investigated. Only CHAPS decreased the enzyme production while Tween 80 and triton X-100 increased the protease activity yield by 181 and 193\%, respectively. 
Effect of different enzyme inhibitors was studied on protease production by the endophytic fungus Penicillium bilaiae TDPEF30. The results illustrated in Table 8 proof that while the fungal protease was completely inhibited by PMSF, $\beta$-mercaptoethanol, DTT and EDTA had no effect on enzyme activity.

Table 8. Effect of metal ions ( $5 \mathrm{mM})$, detergents $(0.1 \%)$ and enzyme inhibitors $(5 \mathrm{mM})$ on protease activity of the endophytic fungus Penicillium bilaiae.

\begin{tabular}{cccc}
\hline Chemicals & Concentrations & Units & Relative Activity (\%) \\
\hline Control & - & - & 100 \\
\hline $\mathrm{Cu}^{2+}$ & 5 & $\mathrm{mM}$ & $21 \pm 3$ \\
\hline $\mathrm{Ca}^{2+}$ & 5 & $\mathrm{mM}$ & $32 \pm 4$ \\
\hline $\mathrm{Fe}^{2+}$ & 5 & $\mathrm{mM}$ & $54 \pm 1$ \\
\hline $\mathrm{Zn}^{2+}$ & 5 & $\mathrm{mM}$ & 100 \\
\hline $\mathrm{Mn}^{2+}$ & 5 & $\mathrm{mM}$ & $114 \pm 2$ \\
\hline $\mathrm{Hg}^{2+}$ & 5 & $\mathrm{mM}$ & $14 \pm 4$ \\
\hline $\mathrm{B}^{3+}$ & 5 & $\mathrm{mM}$ & $191 \pm 1$ \\
\hline $\mathrm{Na}^{2+}$ & 5 & $\mathrm{mM}$ & 100 \\
\hline PMSF & 5 & $\mathrm{mM}$ & 100 \\
\hline EDTA & 5 & $\mathrm{mM}$ & 100 \\
\hline$\beta-M e r c a p t o e t h a n o l$ & 5 & $\mathrm{mM}$ & 100 \\
\hline DTT & 5 & $\mathrm{mM}$ & $181 \pm 1$ \\
\hline Tween 80 & 0.1 & $\%$ & $83 \pm 1$ \\
\hline CHAPS & 0.1 & $\%$ & $193 \pm 2$ \\
\hline Triton X-100 & 0.1 & &
\end{tabular}

\section{Discussion}

The improvement of enzyme production of endophytic microorganisms is the purpose of several investigations owing to their abilities to produce many valuables metabolites with potential bioactivity [31]. In the present study, endophytic fungi were isolated from the root internal tissues of adult date palm trees. These isolates were evaluated for their ability to produce proteases. Plating on skim milk agar medium, as described by Saran et al. [32], is an easy and simple technique to screen for protease activity, although it cannot be recommended for quantitative analysis. The wide use of proteases in biotechnological and industrial processes has attracted researchers to obtain proteolytic enzymes that exhibit various properties suitable for different applications. However, each microbial strain has its specific conditions to maximize protease production. According to our results, the endophytic fungus Penicillium bilaiae TDPEF30 was found to be the best producer of proteases and was selected for further assays of protease production in liquid medium. Few studies have been done to induce protease production from endophytic fungi using a statistical design. Using Czapek Dox as fermentation medium, the TDPEF30 endophytic strain displayed the best level of protease production with $203 \pm 2.1 \mathrm{U} / \mathrm{mL}$. Czapek Dox is an easy to prepare medium with simple components [33].

RSM was carried out to optimize culture medium nutrients and conditions for the production of protease by the endophytic fungus Penicillium bilaiae TDPEF30. At the beginning, the significant variables that influence the protease production were selected using Plackett-Burman Design. Rodriguez et al. [34] as well as Hajji et al. [35] reported that proteases from Penicillium and Aspergillus fungi were affected by temperature and $\mathrm{pH}$. In line with these studies, it was demonstrated in the present study that glucose concentration, $\mathrm{pH}$ and temperature had significant effects on protease 
synthesis by the endophytic fungus Penicillium bilaiae TDPEF30. Then, the BBD was adopted to find out the optimum levels of each significant variable and their interactive effects on protease yield.

Nowadays, application of RSM in biotechnology is increasingly used to statistically determine the best condition for enzyme production, owing to its easy applicability, validity and reliability [36]. In our study, protease production by the endophytic fungus of adult Tunisian date palm was enhanced. However, maximum protease production was achieved at temperature $24.46^{\circ} \mathrm{C}, \mathrm{pH} 6.26$ and $13.75 \mathrm{~g} / \mathrm{L}$ glucose while the other components were used at the lowest level $0.2 \mathrm{~g} / \mathrm{L} \mathrm{MgSO}_{4}, 1.5 \mathrm{~g} / \mathrm{L} \mathrm{NaNO}{ }_{3}$, $0.5 \mathrm{~g} / \mathrm{L} \mathrm{KH}_{2} \mathrm{PO}_{4}$ and $0.5 \mathrm{~g} / \mathrm{L} \mathrm{KCl}$. The RSM process resulted in a proteolytic activity of $1086.95 \mathrm{U} / \mathrm{mL}$, with a 5.8 increase compared to $186.21 \mathrm{U} / \mathrm{mL}$ obtained before optimization. Furthermore, the high degree of similarity between experimental and predicted values reflected the accuracy and the validity of the experimental design applied.

It is well known that microbial protease production is dependent on the availability of both carbon and nitrogen sources, which play a regulatory role in enzyme synthesis [37]. In the current study, various sources of carbon and nitrogen were investigated in order to find the maximum protease production by the endophytic fungus Penicillium bilaiae TDPEF30. The significant effect of sources of carbon and nitrogen either on protease activity or on enzyme production is shown in Figure 3. Concerning carbon source influences, the highest level of protease activity was obtained in presence of the simple carbohydrate mannose with $1907.28 \mathrm{U} / \mathrm{mL}$ followed by complex sources of carbon, namely, sucrose and fructose, with 1649.12 and $1060.15 \mathrm{U} / \mathrm{mL}$, respectively. These different carbon sources have the benefits of their commercial availability. Nonetheless, other carbon sources such as xylose, dextrose, maltose, galactose and starch decreased the protease production by the endophytic fungus TDPEF30 compared to the control glucose-based medium. In general, both organic and inorganic sources of nitrogen were evaluated for their influence on protease production. In the present study, only malt extract and $\mathrm{KNO}_{3}$ increased the proteolytic enzyme yield compared to the control with $\mathrm{NaNO}_{3}$. Our findings are in agreement with the results of Hameed et al. [38], who reported that the addition of mannose induced significant proteolytic activity in etiolated wheat leaves. In addition, Sumantha et al. [39] and Zaferanloo et al. [33] found that protease production by Rhizopus microsporus NRRL 3671 and Alternaria alternata, respectively, was significantly influenced by specific sources of carbon and nitrogen, which could be explained by the specificity of protease enzyme.

Along with carbon and nitrogen sources, the environmental conditions such as $\mathrm{pH}$ medium and temperature could play an important role in the induction or repression of protease activity. Our results indicated that Penicillium bilaiae produced protease at $\mathrm{pH}$ range 5-6.5 with an optimum at six. In addition, maximum protease activity was obtained at $25{ }^{\circ} \mathrm{C}$. In this study, it was found that protease activity increased slightly at $\mathrm{pH} 8$ and $50^{\circ} \mathrm{C}$. These findings could be explained by the presence of isoenzymes produced by the endophytic fungus TDPEF30 during fermentation. This suggests the potentiality of endophytic fungus TDPEF30 to produce a wide range of valuable enzymes with different properties and even in the same class. Enzyme inactivation represents one of the major limitations in the use of proteases in biotechnological processes. The protease produced by the endophytic fungus TDPEF30 lost its activity at $70{ }^{\circ} \mathrm{C}$ and $\mathrm{pH} 10$. Most fungi have an optimum of temperature at the range of $28-30^{\circ} \mathrm{C}$ (Hajji et al., 2008; Germano et al., 2003) [35,40]. However, earlier studies reported that production of proteases from Penicillium species like P. citrinum, P. perpurogerum and P. funculosum was obtained at temperature lower than $30^{\circ} \mathrm{C}$ [41].

The effect of metal ions on protease production by the endophytic fungus Penicillium bilaiae TDPEF30 at a concentration of $5 \mathrm{mM}$ was evaluated under optimal conditions of $\mathrm{pH}$ and temperature. Results indicated that the addition of both $\mathrm{Mn}^{2+}$ and $\mathrm{B}^{3+}$ enhanced the fungal protease activity. In contrast, $\mathrm{Cu}^{2+}, \mathrm{Ca}^{2+}, \mathrm{Fe}^{2+}$ and $\mathrm{Hg}^{2+}$ significantly decreased protease activity. Similar effects of $\mathrm{Mn}^{2+}$ on proteolytic enzyme production were obtained with Penicillium sp. [42]. This finding might be attributed to manganese ion involvement in stabilization of the enzyme molecular structure. In contrast, our findings are in disagreement with the study of Negi \& Banerjee [37], who found that $\mathrm{Ca}^{2+}$ and $\mathrm{Hg}^{2+}$ simulated protease production by Aspergillus awamori. 
The influence of detergents on protease activity was well studied with bacteria, but with fungi, few studies have been reported. Among the detergents, only CHAPS decreased protease activity. Our results are in agreement with the study of Guleria et al. [43], which revealed that the alkaline protease from Bacillus amyloliquefaciens SP1 increased in the presence of triton X-100. Furthermore, Guleria et al. [43] reported the high level of proteolytic activity obtained after incubation of enzyme solution in tween 80 .

The effect of various enzyme inhibitors (used at a concentration of $5 \mathrm{mM}$ ) was determined to evaluate their influence on protease activity. Only PMSF, a well-known as serine protease inhibitor, inhibited protease activity from the endophytic fungus of adult date palm, TDPEF30. We speculate that the protease optimized during the current study can be classified as serine protease.

\section{Conclusions}

The present study is the first to produce protease from a newly isolated fungus from the roots of adult date palm belonging to the Deglet Ennour variety using a statistical design. Further analysis on Czapek Dox medium revealed that Penicillium bilaiae TDPEF30 (GenBank accession for ITS rRNA sequence: KU872795) has the maximum level of protease production. Plackett-Burman design and RSM approaches were employed for optimization of culture and environment conditions and were shown to significantly enhance protease production. The individual and the interactive effects of the three significant factors, namely, temperature, initial $\mathrm{pH}$ and glucose concentration were determined. Maximal levels of protease production from the endophytic fungus Penicillium bilaiae TDPEF30 were obtained at $24.46^{\circ} \mathrm{C}, \mathrm{pH} 6.26,13.75 \mathrm{~g} / \mathrm{L}$ glucose, $0.5 \mathrm{~g} / \mathrm{L} \mathrm{KH}_{2} \mathrm{PO}_{4}, 0.5 \mathrm{~g} / \mathrm{L} \mathrm{KCl}$ and $0.2 \mathrm{~g} / \mathrm{L} \mathrm{MgSO} 4$. Under these conditions, the Penicillium bilaiae TDPEF30 protease activity could reach $1086.95 \mathrm{U} / \mathrm{mL}$. Further studies, such as purification and industrial application of protease from this promising strain, are in progress.

Author Contributions: Conceived and designed the experiments: F.B.M., F.F., A.C.B., A.D., N.G., and L.B.; performed the experiments: F.B.M., F.F., A.C.B., A.D., N.G., L.L. and L.B.; Analysed the data: F.B.M., F.F., A.C.B., A.D., N.G., B.S.A.-A. and L.B.; Contributed reagents/materials/analysis tools: F.F., A.C.B., F.N.A., N.G., T.O., B.S.A.-A. and L.B.; Wrote and enriched the literature: F.B.M., F.F., A.C.B., A.D., N.G., B.S.A.-A. and L.B.; and read the manuscript F.B.M., F.F., A.C.B., A.D., T.O., N.G., B.S.A.-A. and L.B.

Funding: Financial support of the Tunisian Ministry of Higher Education and Scientific Research is gratefully acknowledged. LL is indebted to the Ministry of Education, Science, Research and Sport of the Slovak Republic for financial support in the frame of the project "VEGA 1/0061/16". Part of the study was financially supported by the Funding: Grant PROZEL No. 490321 of the National Centre for Research and Development (NCBiR) (Grant to T.O.).

Conflicts of Interest: The authors declare no conflict of interest.

\section{References}

1. Zheng, Y.K.; Qiao, X.G.; Miao, C.P.; Liu, K.; Chen, Y.W.; Xu, L.H.; Zhao, L.X. Diversity, distribution and biotechnological potential of endophytic fungi. Ann. Microbiol. 2016, 66, 529-542. [CrossRef]

2. Rai, M.; Agarkar, G. Plant-fungal interactions: What triggers the fungi to switch among lifestyles? Crit. Rev. Microbiol. 2016, 42, 428-438. [CrossRef] [PubMed]

3. Hiruma, K.; Gerlach, N.; Sacristan, S.; Nakano, R.T.; Hacquard, S.; Kracher, B.; Neumann, U.; Ramirez, D.; Bucher, M.; O'Connell, R.J.; et al. Root Endophyte Colletotrichum tofieldiae confers plant fitness benefits that are phosphate status dependent. Cell 2016, 165, 464-474. [CrossRef] [PubMed]

4. Barelli, L.; Moonjely, S.; Behie, S.W.; Bidochka, M.J. Fungi with multifunctional lifestyles: Endophytic insect pathogenic fungi. Plant Mol. Biol. 2016, 90, 657-664. [CrossRef] [PubMed]

5. Correa, R.C.G.; Rhoden, S.A.; Mota, T.R.; Azevedo, J.L.; Pamphile, J.A.; de Souza, C.G.; Polizeli, M.L.; Bracht, A.; Peralta, R.M. Endophytic fungi: Expanding the arsenal of industrial enzyme producers. J. Ind. Microbiol. Biotechnol. 2014, 41, 1467-1478. [CrossRef] [PubMed] 
6. Kumar, D.J.M.; Rajan, R.; Lawrence, L.; Priyadarshini, S.; Chittybabu, S.; Kalaichelvan, P.T. Destaining and dehairing capability of partially purified Bacillus subtilis protease from optimized fermentation medium. Asian J. Exp. Biol. Sci. 2012, 3, 613-620.

7. Laxman, R.S.; Sonawane, A.P.; More, S.V.; Rao, B.S.; Rele, M.V.; Jogdand, V.V.; Deshpande, V.V.; Rao, M.B. Optimization and scale up of production of alkaline protease from Conidiobolus coronatus. Process Biochem. 2005, 40, 3152-3158. [CrossRef]

8. Gupta, R.; Beg, Q.K.; Lorenz, P. Bacterial alkaline proteases: Molecular approaches and industrial applications. Appl. Microbiol. Biotechnol. 2002, 59, 15-32. [CrossRef]

9. Nirmal, N.P.; Shankar, S.; Laxman, R.S. Fungal proteases: An overview. Int. J. Biotechnol. Biosci. 2011, 1, 1-40.

10. Lageiro, M.M.; Moura, M.J.; Reis, A.; Ferreira, M.J.C. Microbial proteases application in leather industry. J. Biotechnol. 2007, 131, 239-240. [CrossRef]

11. Vishwanatha, K.S.; Appu Rao, A.G.; Singh, S.A. Production and characterization of a milk-clotting enzyme from Aspergillus oryzae MTCC 5341. Appl. Microbiol. Biotechnol. 2010, 85, 1849-1859. [CrossRef] [PubMed]

12. Agrawal, D.; Patidar, P.; Banerjee, T.; Patil, S. Alkaline protease production by a soil isolate of Beauveria felina under SSF condition: Parameter optimization and application to soy protein hydrolysis. Process Biochem. 2005, 40, 1131-1136. [CrossRef]

13. Gao, Y.L.; Jiang, H.H. Optimization of process conditions to inactivate Bacillus subtilis by high hydrostatic pressure and mild heat using response surface methodology. Biochem. Eng. J. 2005, 24, 43-48. [CrossRef]

14. Soumya, P.S.; Lakshmi, M.S.K.; Nambisan, P. Application of response surface methodology for the optimization of laccase production from Pleurotus ostreatus by solid state fermentation on pineapple leaf substrate. J. Sci. Ind. Res. 2016, 75, 306-314.

15. Xue, J.L.; Zhao, S.; Liang, R.M.; Yin, X.; Jiang, S.X.; Su, L.H.; Yang, Q.; Duan, C.J.; Liu, J.L.; Feng, J.X. A biotechnological process efficiently co-produces two high value-added products, glucose and xylooligosaccharides, from sugarcane bagasse. Bioresour. Technol. 2016, 204, 130-138. [CrossRef] [PubMed]

16. Mandal, N.; Mondal, S.; Mondal, A.; Mukherjee, K.; Mondal, B. Response surface modelling of Cu(II) removal from wastewater using fish scale-derived hydroxyapatite: Application of Box-Behnken experimental design. Desalin. Water Treat. 2016, 57, 15410-15423. [CrossRef]

17. Hallmann, J.; Berg, G.; Schulz, B. Isolation Procedures for Endophytic Microorganisms; Springer: Brelin/Heidelberg, Germany; New York, NY, USA, 2007.

18. Vega, F.E.; Pava-Ripoll, M.; Posada, F.; Buyer, J.S. Endophytic bacteria in Coffea arabica L. J. Basic Microbiol. 2005, 45, 371-380. [CrossRef] [PubMed]

19. Belbahri, L.; Calmin, G.; Pawlowski, J.; Lefort, F. Phylogenetic analysis and real time PCR detection of a presumably undescribed Peronospora species on sweet basil and sage. Mycol. Res. 2005, 109, 1276-1278. [CrossRef]

20. White, T.J.; Bruns, T.; Lee, S.; Taylor, J.W. Amplification and direct sequencing of fungal ribosomal RNA genes for phylogenetics. In PCR Protocols, a Guide to Methods and Applications; Innis, M.A., Gelfan, D.H., Sninsky, J.J., White, T., Eds.; Academic Press: San Diego, CA, USA, 1990; pp. 315-322.

21. Thompson, J.D.; Higgins, D.G.; Gibson, T.J. CLUSTAL W: Improving the sensitivity of progressive multiple sequence alignment through sequence weighting, position-specific gap penalties and weight matrix choice. Nucleic Acid Res. 1994, 22, 4673-4680. [CrossRef]

22. Guindon, S.; Gascuel, O. A simple, fast and accurate algorithm to estimate large phylogenies by maximum likelihood. Syst. Biol. 2003, 52, 696-704. [CrossRef]

23. Molitoris, H.P. Methods for determination of enzymatic activities of marine fungi. Czech Mycol. 2000, 52, 97-124.

24. Kembhavi, A.A.; Kulkarni, A.; Pant, A.A. Salt-tolerant and thermostable alkaline protease from Bacillus subtilis NCIMNo 64. Appl. Biochem. Biotechnol. 1993, 38, 83-92. [CrossRef] [PubMed]

25. Li, X.; Xu, T.; Ma, X.; Guo, K.; Kai, L.; Zhao, Y.; Jia, X.; Ma, Y. Optimization of culture conditions for production of cis-epoxysuccinic acid hydrolase using response surface methodology. Bioresour. Technolol. 2008, 99, 5391-5396. [CrossRef] [PubMed]

26. Plackett, R.L.; Burman, J.P. The design of optimum multifactorial experiments. Biometrika 1946, 33, 305-325. [CrossRef] 
27. Wang, Q.; Hou, Y.; Xu, Z.; Miao, J.; Li, G. Optimization of cold-active protease production by the psychrophilic bacterium Colwellia sp. NJ341 with response surface methodology. Bioresour. Technol. 2007, 99, 1926-1931. [CrossRef] [PubMed]

28. Xiao, Z.J.; Liu, P.H.; Qin, J.Y.; Xu, P. Statistical optimization of medium components for enhanced acetoin production from molasses and soybean meal hydrolysate. Appl. Microbiol. Biotechnol. 2007, 74, 61-68. [CrossRef] [PubMed]

29. Box, G.E.P.; Behnken, D.W. Some new three level designs for the study of quantitative variables. Technometrics 1960, 2, 455-475. [CrossRef]

30. Li, X.; Zhu, D.; Wang, X. Evaluation on dispersion behavior of the aqueous copper nano-suspensions. J. Colloid Interface Sci. 2007, 310, 456-463. [CrossRef]

31. Li, J.; Li, L.; Si, Y.K.; Jiang, X.J.; Guo, L.D.; Che, Y.S. Virgatolides A-C, benzannulated spiroketals from the plant endophytic fungus Pestalotiopsis virgatula. Org. Lett. 2011, 13, 2670-2673. [CrossRef]

32. Saran, S.; Isar, J.; Saxena, R.K. A modified method for the detection of microbial proteases on agar plates using tannic acid. J. Biochem. Biophys. Methods 2007, 70, 697-699. [CrossRef]

33. Zaferanloo, B.; Quang, T.D.; Daumoo, S.; Ghorbani, M.M.; Mahon, P.J.; Palombo, E.A. Optimization of protease production by endophytic fungus, Alternaria alternata, isolated from an Australian native plant, World. J. Microbiol. Biotechnol. 2014, 6, 1755-1756. [CrossRef] [PubMed]

34. Rodriguez, R.J.; White, J.F., Jr.; Arnold, A.E.; Redman, R.S. Endophytes: Diversity and functional roles. New Phytol. 2008, 182, 314-330. [CrossRef] [PubMed]

35. Hajji, M.; Rebai, A.; Gharsallah, N.; Nasri, M. Optimization of alkaline protease production by Aspergillus clavatus ES1 in Mirabilis jalapa tuber powder using statistical experimental design. Appl. Microbiol. Biotechnol. 2008, 79, 915-923. [CrossRef] [PubMed]

36. Haaland, P.D. Experimental Design in Biotechnology; Marcel Dekker: New York, NY, USA, 1989.

37. Negi, S.; Banerjee, R. Optimization of culture parameters to enhance production of amylase and protease from Aspergillus awamori in a single fermentation. Afr. J. Biochem. Res. 2010, 4, 73-80.

38. Hameed, A.; Iqbal, N.; Malik, S.A. Mannose-induced modulations in antioxidants, protease activity, lipid peroxidation, and total phenolics in etiolated wheat leaves. J. Plant Growth Regul. 2009, 28, 58-65. [CrossRef]

39. Sumantha, A.; Deepa, P.; Sandhya, C.; Szakacs, G.; Soccol, C.R.; Pandey, A. Rice bran as a substrate for proteolytic enzyme production. Braz. Arch. Biol. Technol. 2006, 49, 843-851. [CrossRef]

40. Germano, S.; Pandey, A.; Osaka, C.A.; Rocha, S.N.; Soccol, C.R. Characterization and stability of proteases from Penicillium sp. produced by solid-state fermentation, Enzyme. Enzyme Microb. Technol. 2003, 32, 246-251. [CrossRef]

41. Haq, I.; Mukhtar, Z.A.; Riaz, N. Protease biosynthesis by mutant strain of Penicillium griseoroseum and cheese formation. Pak. J. Biol. Sci. 2004, 7, 1473-1476.

42. Agrawal, D.; Patidar, P.; Banerjee, T.; Patil, S. Production of alkaline protease by Penicillium sp. under conditions and its application to soy protein hydrolysis. Process Biochem. 2004, 39, 977-981. [CrossRef]

43. Guleria, S.; Walia, A.; Chauhan, A.; Shirkot, C.K. Purification and characterization of detergent stable alkaline protease from Bacillus amyloliquefaciens SP1 isolated from apple rhizosphere. J. Basic Microbiol. 2016, 56, 138-152. [CrossRef]

(C) 2019 by the authors. Licensee MDPI, Basel, Switzerland. This article is an open access article distributed under the terms and conditions of the Creative Commons Attribution (CC BY) license (http://creativecommons.org/licenses/by/4.0/). 